Article

\title{
Serpentine-Hisingerite Solid Solution in Altered Ferroan Peridotite and Olivine Gabbro
}

\author{
Benjamin M. Tutolo ${ }^{1, *(\mathbb{D}, \text { Bernard W. Evans }}{ }^{2}$ and Scott M. Kuehner ${ }^{2}$ \\ 1 Department of Geoscience, University of Calgary, 2500 University Drive NW, Calgary, AB T2N 1N4, Canada \\ 2 Department of Earth and Space Sciences, University of Washington, Seattle, WA 98195-1310, USA; \\ bwevans@uw.edu (B.W.E.); kuehner@uw.edu (S.M.K.) \\ * Correspondence: benjamin.tutolo@ucalgary.ca
}

Received: 20 November 2018; Accepted: 11 January 2019; Published: 15 January 2019

check for updates

\begin{abstract}
We present microanalyses of secondary phyllosilicates in altered ferroan metaperidotite, containing approximately equal amounts of end-members serpentine $\left(\left(\mathrm{Mg}_{,} \mathrm{Fe}^{2+}\right)_{3} \mathrm{Si}_{2} \mathrm{O}_{5}(\mathrm{OH})_{4}\right)$ and hisingerite $\left(\square \mathrm{Fe}^{3+}{ }_{2} \mathrm{Si}_{2} \mathrm{O}_{5}(\mathrm{OH})_{4} \cdot \mathrm{nH}_{2} \mathrm{O}\right)$. These analyses suggest that all intermediate compositions can exist stably, a proposal that was heretofore impossible because phyllosilicate with the compositions reported here have not been previously observed. In samples from the Duluth Complex (Minnesota, USA) containing igneous olivine $\mathrm{Fa}_{36-44}$, a continuous range in phyllosilicate compositions is associated with hydrothermal $\mathrm{Mg}$ extraction from the system and consequent relative enrichments in $\mathrm{Fe}^{2+}, \mathrm{Fe}^{3+}$ (hisingerite), $\mathrm{Si}$, and $\mathrm{Mn}$. Altered ferroan-olivine-bearing samples from the Laramie Complex (Wyoming, USA) show a compositional variability of secondary FeMg-phyllosilicate (e.g., Mg-hisingerite) that is discontinuous and likely the result of differing igneous olivine compositions and local equilibration during alteration. Together, these examples demonstrate that the products of serpentinization of ferroan peridotite include phyllosilicate with iron contents proportionally larger than the reactant olivine, in contrast to the common observation of Mg-enriched serpentine in "traditional" alpine and seafloor serpentinites To augment and contextualize our analyses, we additionally compiled greenalite and hisingerite analyses from the literature. These data show that greenalite in metamorphosed banded iron formation contains progressively more octahedral-site vacancies (larger apfu of $\mathrm{Si}$ ) in higher $\mathrm{X}_{\mathrm{Fe}}$ samples, a consequence of both increased hisingerite substitution and structure modulation (sheet inversions). Some high-Si greenalite remains ferroan and seems to be a structural analogue of the highly modulated sheet silicate caryopilite. Using a thermodynamic model of hydrothermal alteration in the Fe-silicate system, we show that the formation of secondary hydrothermal olivine and serpentine-hisingerite solid solutions after primary olivine may be attributed to appropriate values of thermodynamic parameters such as elevated $a_{\mathrm{SiO}_{2}(a q)}$ and decreased $a_{\mathrm{H}_{2}(a q)}$ at low temperatures $\left(\sim 200^{\circ} \mathrm{C}\right)$. Importantly, recent observations of Martian rocks have indicated that they are evolved magmatically like the ferroan peridotites analyzed here, which, in turn, suggests that the processes and phyllosilicate assemblages recorded here are more directly relevant to those occurring on Mars than are traditional terrestrial serpentinites.
\end{abstract}

Keywords: serpentine; hisingerite; greenalite; Mars; nakhlite

\section{Introduction}

The process of Fe oxidation and coupled $\mathrm{H}_{2}$ production during serpentine formation has attracted sustained research interest across the geological, mineralogical, biological, and planetary sciences over the past few decades (e.g., References [1-6]), although the presence of oxidized iron in serpentine-group minerals has been acknowledged since at least the late 1950s [7-10]. Much of 
the recent interest in $\mathrm{Fe}^{3+}$-bearing serpentine has been instigated by the growing recognition that magnetite-free serpentinites in many cases still contain abundant $\mathrm{Fe}^{3+}$, in the form of $\mathrm{Fe}^{3+}$-bearing serpentine and, hence, like their magnetite-bearing counterparts, also produce $\mathrm{H}_{2}$, a principal feedstock for chemolithoautrophic organisms (e.g., Reference [11]), during their formation [12-14]. This observation has in turn led to a proliferation of geochemical models seeking to constrain the formation and stability of $\mathrm{Fe}^{3+}$-bearing serpentine solid solutions during hydrothermal alteration of olivine (e.g., References [4,15-17]). Nonetheless, there are few empirical data to constrain the predictions produced by these ideal solid-solution models, since the vast majority of research and modeling efforts have focused on serpentinization of mantle peridotite, where the primary olivine is highly magnesian ( $90 \% \mathrm{Mg}$ end-member) and the product serpentine is invariably enriched in $\mathrm{Mg}$ relative to the primary olivine. In the present study, we address this knowledge gap by presenting new and compiled analyses of Fe-rich serpentines formed in mafic igneous intrusions, ore deposits, Martian nakhlite meteorites, and banded iron formations. Together, these analyses demonstrate complete miscibility between the end-members greenalite $\left(\mathrm{Fe}_{3} \mathrm{Si}_{2} \mathrm{O}_{5}(\mathrm{OH})_{4}\right)$, $\mathrm{Mg}$-serpentine $\left(\mathrm{Mg}_{3} \mathrm{Si}_{2} \mathrm{O}_{5}(\mathrm{OH})_{4}\right)$, and hisingerite $\left(\mathrm{Fe}_{2} \mathrm{Si}_{2} \mathrm{O}_{5}(\mathrm{OH})_{4} \cdot \mathrm{nH}_{2} \mathrm{O}\right)$. These observations, in turn, can form the basis of more robust constraints on geochemical models of $\mathrm{Fe}^{3+}$ incorporation into serpentine and accompanying $\mathrm{H}_{2}$ production.

\subsection{Mechanisms of $\mathrm{Fe}^{3+}$ Substitution into Serpentine}

The substitution of $\mathrm{Fe}^{3+}$ atoms into the serpentine structure is crystallographically favorable because the smaller ionic radius of $\mathrm{Fe}^{3+}$ compared to $\mathrm{Mg}^{2+}$ works to alleviate the misfit between the octahedral and tetrahedral layers [5,18]. Three mechanisms are known to account for the incorporation of $\mathrm{Fe}^{3+}$ into the serpentine structure (e.g., Reference [14]): (1) ferri-tschermaks substitution; (2) deprotonation; and (3) octahedral-site vacancies. These mechanisms are discussed individually below.

In most instances of altered mantle, ocean-floor, and ophiolite peridotite (i.e., "conventional" serpentinites), $\mathrm{Fe}^{3+}$ is accommodated at least in part via the ferri-tschermaks substitution, in which $\mathrm{Fe}^{3+}$ is shared equally between octahedral $\left({ }^{[6]} \mathrm{Fe}^{3+}\right)$ and tetrahedral $\left({ }^{[4]} \mathrm{Fe}^{3+}\right)$ sites (e.g., References $\left.[4,19-21]\right)$. The corresponding exchange vector $\mathrm{Fe}^{3+}{ }_{2}\left(\mathrm{MgSi}_{-1}\right.$ extends from serpentine toward a magnesian analogue of cronstedtite: $(\mathrm{Mg}, \mathrm{Fe})_{2}\left(\mathrm{Fe}^{3+}\right)\left(\mathrm{Fe}^{3+} \mathrm{SiO}_{5}\right)(\mathrm{OH})_{4}$. Chemographic relations in the (projected) ternary system $\mathrm{Si}-\mathrm{Mg}-\mathrm{Fe}$ would suggest that this substitution is likely to be prevalent in serpentinites containing the Si-free minerals brucite and NiFe alloy (awaruite). Published analyses of such lizardites show $\mathrm{Si}$ atoms per formula unit covarying inversely 1:2 with total iron and ranging down to around $1.8[21,22]$.

An alternative mechanism for incorporating $\mathrm{Fe}^{3+}$ in serpentine involves deprotonation: $\mathrm{Fe}^{3+}\left(\mathrm{Fe}^{2+} \mathrm{H}\right)_{-1}[14,21,23]$; it produces compositions projecting toward $\left(\mathrm{Mg}_{2} \mathrm{Fe}^{3+}\right) \mathrm{Si}_{2} \mathrm{O}_{6}(\mathrm{OH})_{3}$. This "oxy" form of serpentine leaves cation proportions unchanged, so its presence is not identifiable through electron microprobe analysis. In many lizardites, it operates in combination with the ferri-tschermaks substitution, such that ${ }^{[6]} \mathrm{Fe}^{3+}$ exceeds ${ }^{[4]} \mathrm{Fe}^{3+}$. Differential thermal analysis suggests this mechanism for $\mathrm{Fe}^{3+}$ incorporation in serpentine may function in both negative and positive directions [21].

In a third possible mechanism, $\mathrm{Fe}^{3+}$ substitution on octahedral sites of serpentine is balanced by octahedral-site vacancies [10]. The composition vector resulting from this substitution ultimately yields hisingerite, whose formula can be written as $\square \mathrm{Fe}^{3+}{ }_{2} \mathrm{Si}_{2} \mathrm{O}_{5}(\mathrm{OH})_{4} \cdot \mathrm{nH}_{2} \mathrm{O}$ [24]. The relative proportion of tetrahedral site to total cations in this substitution changes from 0.40 to 0.50 , while both end-members have $\sim 0.7 \mathrm{~nm}(7 \AA)$ basal spacing. This substitution occurs in bastite lizardite (altered chain silicate) in some ocean-floor serpentinites (Figure 5 from Evans et al. [22]) and, as we show below, also in altered ferroan peridotite and olivine gabbro samples from large, layered mafic intrusions. Importantly, this "serpentine" is not the same as the red-yellow "iddingsite" that forms by weathering of olivine phenocrysts in basalt, which is composed of smectite and goethite [25]. The amount of ferric iron 
introduced by any of these three mechanisms is necessarily small in highly magnesian whole-rock compositions such as serpentinized oceanic mantle, seafloor, and ophiolite peridotites.

\subsection{Serpentine-Hisingerite Miscibility}

In spite of the community-wide interest in understanding the oxidation state of $\mathrm{Fe}$ in the alteration products of serpentinization, the extent of miscibility of serpentine and hisingerite in nature is poorly known. Hisingerite occurs primarily in ore deposits, where its content of serpentine end-member (greenalite) is small, at most $20 \%$ ( $\mathrm{Si} / \Sigma$ Cations $>0.477$ ). However, recent analyses of serpentines in layered mafic intrusions indicate that serpentine in these environments can also contain significant amounts of hisingerite [26]. These rocks, therefore, present a unique opportunity to study the miscibility between hisingerite and greenalite over a much broader range than the ore deposits that have been the dominant source of study to date.

Figure 1 shows, in terms of iron-magnesium ratio $\mathrm{X}_{\mathrm{Fe}}(=\mathrm{Fe} /(\mathrm{Mg}+\mathrm{Fe}))$ and $\mathrm{Si} / \Sigma$ Cations, the theoretical wedge-shaped compositional space that can potentially be occupied by serpentine-hisingerite solid solutions. Because of the variable octahedral-site vacancy, total cations per formula unit vary from five in ideal serpentine to four in ideal hisingerite. Thus, $\mathrm{Si} / \Sigma$ Cations, the y-axis in Figure 1, is 0.40 for 0 mol.\% hisingerite, 0.50 for $100 \mathrm{~mol} \%$ hisingerite, and 0.444 for $50 \mathrm{~mol}$ \% hisingerite. The 50:50 boundary between $\mathrm{Mg}$-serpentine and hisingerite is at the Figure 1 $\mathrm{x}$-axis value of $\mathrm{Fe} /(\mathrm{Fe}+\mathrm{Mg})=0.4$. Within this composition space, isopleths of formula amounts of $\mathrm{Fe}^{2+}$ or $\mathrm{Fe}^{3+} / \Sigma \mathrm{Fe}$ (labeled along the right side of the prism in Figure 1) radiate up and out from $\mathrm{Mg}$-serpentine, whereas isopleths of $\mathrm{Mg}$ atoms per formula unit (apfu, labeled along the bottom of the prism in Figure 1) are steep with a negative slope. In other words, every point within the prism corresponds to a simple basic formula referenced to two silicon apfu. It is important to note that $\mathrm{Al}_{2} \mathrm{O}_{3}$, the other most likely tetrahedral site cation in serpentine, is typically a very minor component in our sampling of the phyllosilicate in altered ferroan peridotites (frequently below detection limit and seldom more than $0.3 \mathrm{wt} . \%$; Table 1 ).

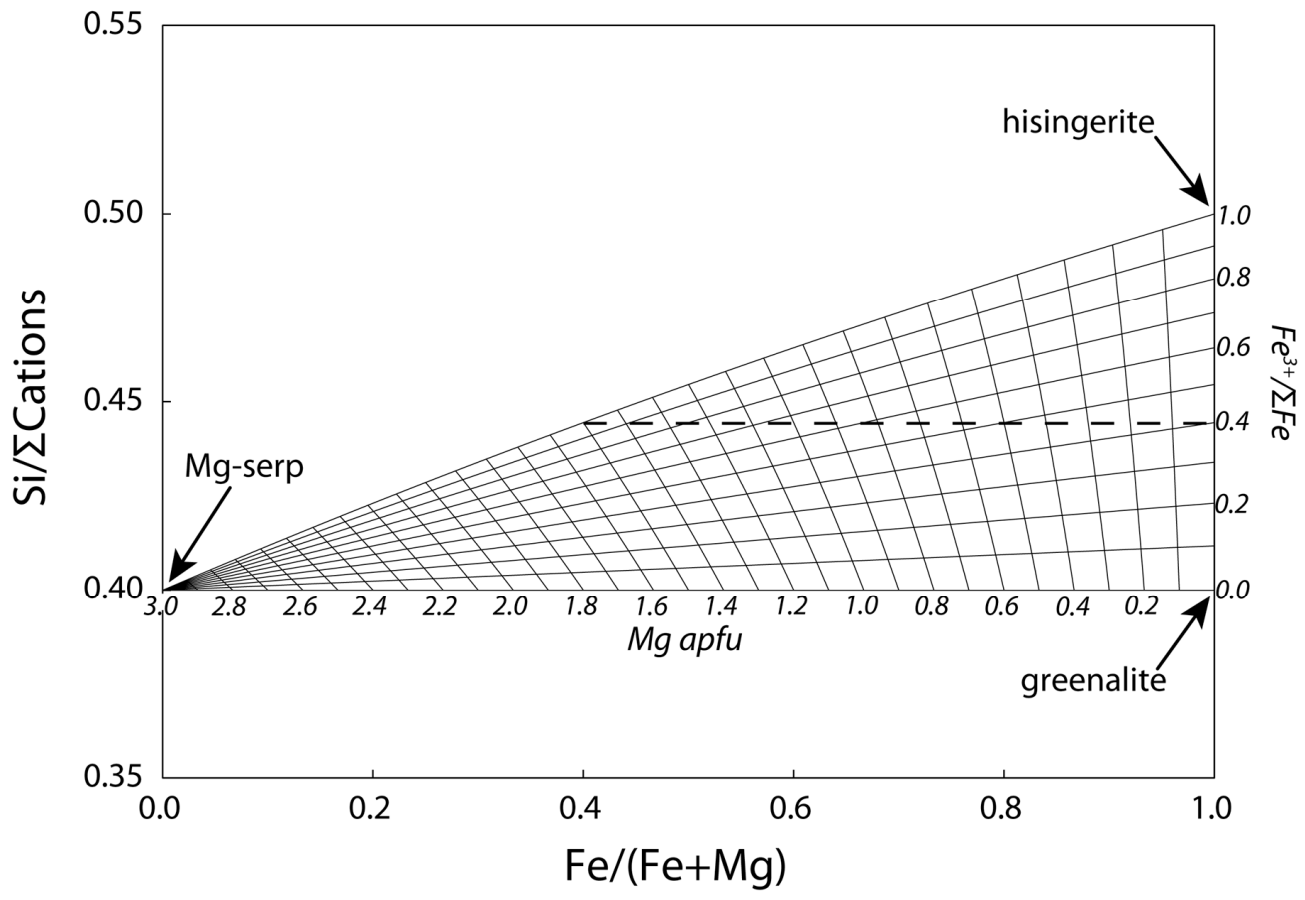

Figure 1. Possible composition space for Mg-serpentine/greenalite/hisingerite solid solutions. Note that the upper compositional limit is slightly curved concave down. Isopleths for $\mathrm{Mg}$ and $\mathrm{Fe}^{3+} / \Sigma \mathrm{Fe}$ refer to a formula unit containing two silicon atoms. The horizontal dashed line at $\mathrm{Si} / \Sigma \mathrm{Cations}=0.444$ represents the lower $50 \%$ boundary of hisingerite compositions. 
The isopleths in Figure 1 only apply to the greenalite/hisingerite/Mg-serpentine system when octahedral-site vacancy is created by the presence of $\mathrm{Fe}^{3+}$. In other words, these isopleths are not applicable in instances where octahedral vacancy is a consequence of a modulated sheet-silicate structure, as is potentially the case for greenalite (see below), or in the case of ferri-tschermaks substitution. In addition, contamination by another layer silicate will render the isopleths inapplicable to the measured composition. Given the relatively poor crystallinity of hisingerite [24] and the low temperature of its formation, it is likely that its paragenesis will not perfectly conform with the usual constraints of equilibrium phase petrology. Indeed, as discussed below, analyses of many samples of hisingerite in the literature indicate "excess" Si (T/ $\Sigma$ Cations $>0.50)$, apparently owing to the presence of some saponite or nontronite impurity [24].

Table 1. Average microprobe analyses of clusters of hisingerite and greenalite.

\begin{tabular}{|c|c|c|c|c|c|c|c|c|}
\hline Location & \multicolumn{2}{|c|}{ Duluth Complex } & \multicolumn{3}{|c|}{ Laramie Complex } & \multicolumn{2}{|c|}{ Overlook Ore Deposit } & \multirow{3}{*}{$\begin{array}{c}\text { Mars } \\
\text { Nakhla } \\
\text { His }\end{array}$} \\
\hline Sample & DM561A & Bardon Peak & LAC-1B & Oxide Body & GR22C & $19-821$ & $19-821$ & \\
\hline Mineral & $\mathrm{Mg}-\mathrm{His}$ & $\mathrm{Mg}-\mathrm{His}$ & Gre-His & His & His & His? & Gre? & \\
\hline Oxide & \multicolumn{8}{|c|}{ Weight Percent } \\
\hline $\mathrm{SiO}_{2}$ & 39.49 & 39.13 & 37.74 & 42.67 & 37.82 & 40.46 & 40.46 & 43.36 \\
\hline $\mathrm{Fe}_{2} \mathrm{O}_{3} \mathrm{t}$ & 29.96 & 34.22 & & 35.83 & 46.94 & 51.38 & & 36.57 \\
\hline $\mathrm{FeO} \mathrm{t}$ & & & 33.65 & & & & 46.23 & \\
\hline $\mathrm{MnO}$ & 0.32 & 0.34 & 0.25 & 0.15 & 0.49 & 0.58 & 0.58 & 0.44 \\
\hline $\mathrm{MgO}$ & 12.73 & 13.01 & 13.99 & 7.46 & 2.15 & 1.86 & 1.86 & 6.09 \\
\hline $\mathrm{NiO}$ & 0.13 & 0.08 & 0.05 & 0.05 & 0.01 & 0.02 & 0.02 & 0.02 \\
\hline $\mathrm{Si}$ & 2.078 & 1.989 & 2.115 & 2.131 & 1.994 & 1.975 & 1.956 & 2.17 \\
\hline Al & 0.003 & 0.010 & 0.003 & 0.072 & 0.003 & 0.035 & 0.035 & 0.064 \\
\hline $\mathrm{Cr}$ & 0.001 & 0 & 0.001 & 0.001 & 0.002 & 0.002 & 0.001 & 0.001 \\
\hline $\mathrm{Fe}^{3+}$ & 1.186 & 1.309 & & 1.346 & 1.862 & 1.887 & & 1.377 \\
\hline $\mathrm{Fe}^{2+}$ & & & 1.577 & & & & 1.869 & \\
\hline Mn & 0.014 & 0.015 & 0.012 & 0.006 & 0.022 & 0.024 & 0.024 & 0.019 \\
\hline Mg & 0.999 & 0.986 & 1.167 & 0.556 & 0.169 & 0.135 & 0.134 & 0.454 \\
\hline $\mathrm{Ca}$ & 0.045 & 0.043 & 0.009 & 0.043 & 0.021 & 0.005 & 0.004 & 0.022 \\
\hline Total & 4.326 & 4.352 & 4.884 & 4.155 & 4.073 & 4.063 & 4.023 & 4.107 \\
\hline $\mathrm{Si} / \Sigma$ Cations & 0.48 & 0.457 & 0.433 & 0.513 & 0.49 & 0.486 & 0.486 & 0.528 \\
\hline
\end{tabular}

Abbreviations: "Anh." = anhydrous; "His" = hisingerite; "Gre" = greenalite. For the Overlook samples, analyses are given considering $\mathrm{Fe}$ as either all $\mathrm{Fe}_{2} \mathrm{O}_{3}$ or all $\mathrm{FeO}$ in order to demonstrate the high anhydrous total when considering all $\mathrm{Fe}$ in this sample is $\mathrm{Fe}_{2} \mathrm{O}_{3}$.

\section{Methods}

\subsection{Electron Microprobe Analyses}

Ideally, measurement of the amount of ferric iron in any given serpentine requires analytical treatment of $\mathrm{Fe}^{2+}$ and $\mathrm{Fe}^{3+}$ as independent quantities, and this may be done on mineral separates using Mössbauer spectroscopy [19-21] and in situ using microbeam x-ray absorption near-edge spectroscopy (XANES) [27-29]. Nonetheless, in more ferroan peridotites, such as those that are the subject of this study, the amounts of hisingerite and greenalite components in the serpentinite product are sufficiently large that, unless impure, they can reasonably be estimated on the basis of two chemical parameters amenable to routine electron microprobe (EMP) analyses, namely the $\mathrm{Mg} / \Sigma \mathrm{Fe}$ ratio and the relative proportions of tetrahedral-site and octahedral-site cations (e.g., Reference [14]). Electron microprobe analyses in this work were performed by wavelength-dispersive spectrometry on a JEOL 733 instrument fitted with Geller Version 7 automation. Our library of standards included synthetic oxides, chromite and fayalite, and natural Mg-olivine, Crystal Bay plagioclase, 6927 clinopyroxene, 
and Nuevo garnet. Analytical conditions were $15 \mathrm{kV}$ accelerating potential, $3 \mathrm{nA}$ beam current, $3 \mu \mathrm{m}$ beam diameter, and counting times for $0.4 \%$ counting error $(1 \sigma)$ or $40 \mathrm{~s}$ for minor elements. Raw data were corrected with the CITZAF package.

\subsection{Thermodynamic Calculations}

To assess the thermodynamic conditions under which greenalite-hisingerite solid solutions are stable, we produced a thermodynamic database at $1 \mathrm{kbar}$ and $25-450{ }^{\circ} \mathrm{C}$ for use in the Geochemist's Workbench (GWB) version 12.0.4 [30] using the DBCreate software package [31]. Thermodynamic properties for fayalite and magnetite in this database are from Helgeson et al. [32], those for $\mathrm{SiO}_{2}(\mathrm{aq})$ are from Sverjensky et al. [33], and $\mathrm{Fe}(\mathrm{OH})_{2}$ properties were taken from McCollom and Bach [34]. All other thermodynamic data for relevant aqueous species were taken from the standard SUPCRT92 database [35]. After its creation, this GWB database was augmented with equilibrium constants calculated from thermodynamic properties for hisingerite, greenalite, cronstedtite, and minnesotaite reported by Blanc et al. [36], or, in the case of cronstedtite and hisingerite, calculated using estimation techniques detailed therein. Internal consistency was ensured through the use of identical thermodynamic properties for relevant aqueous species during calculation of the solubility constants for these minerals.

\section{Results}

\subsection{Layered Mafic Intrusions}

\subsubsection{Duluth Complex}

Evans et al. [26] presented analyses of iron-rich phyllosilicates and magnesian fayalite ( $\left.\mathrm{Fa}_{53}-80\right)$ that formed as a result of low-temperature alteration, attended by Mg-depletion, of ferroan forsterite ( $\mathrm{Fa}_{38-44}$ ) in two peridotite samples from the layered mafic Duluth igneous complex (Minnesota, USA). Spot analyses of the phyllosilicates illustrated a continuous series of compositions from $\mathrm{Mg}$-serpentine to $\mathrm{Mg}$-hisingerite, but those authors left open the question of whether the series represented a genuine range of solid-solution compositions or simply mixtures, presumably interlayered, of two end-member compositions.

Further EMP investigation of these samples, and another from the Duluth Complex (Bardon Peak, igneous olivine $\mathrm{Fa}_{36}$ ) from the same hand sample as that analyzed by Tutolo et al. [37], reinforces the continuous compositional nature of the phyllosilicate (Figure 2). In addition, these analyses emphasize the presence of clusters of phyllosilicate compositions in the $\mathrm{X}_{\mathrm{Fe}}$ range $0.51-0.62$, and $\mathrm{Si} / \Sigma$ Cations $=$ 0.45-0.49 (Table 1). More Fe-rich phyllosilicate compositions (aside from manganoan chamosite) in the Duluth samples are rare. However, samples from the Laramie Complex (Wyoming, USA, see below) show that this rarity cannot be attributed to the intrinsic instability of compositions richer in Fe than $\mathrm{X}_{\mathrm{Fe}}=0.62$ (Figure 3). Accordingly, we view the continuous trends in Figure 2 not as a product of physical mixing of $\mathrm{Mg}$-serpentine and $\mathrm{Mg}$-hisingerite, but rather as representing stable solid-solution compositions. The trajectories start from a silica-undersaturated lizardite (see also Evans et al. [26]) with modest levels of $\mathrm{Fe}^{3+}$, and obliquely cross isopleths of $\mathrm{Fe}^{3+} / \Sigma \mathrm{Fe}$ ratio (Figure 1) to emerge above the top of the theoretical composition envelope (Figure 2). The latter feature is most likely attributable to contamination by a clay mineral such as saponite, as discussed below.

Importantly, the Bardon Peak sample, as in those samples presented by Evans et al. [26], provides a further example of early fayalite $\left(\mathrm{Fa}_{61-74}\right)$ formation as a result of the Mg-depletion during serpentinization. As shown thermodynamically below, the progressive growth of individual solid-solution compositions following the initial fayalite formation would have been largely determined by locally and temporally evolving thermodynamic properties of the system (i.e., increasing activities of silica $\left(a_{\mathrm{SiO}_{2}(a q)}\right)$ and decreasing activity of hydrogen $\left(a_{\mathrm{H}_{2}(a q)}\right)$ in the solution), driven by a hydrothermal alteration process that involved major removal of $\mathrm{Mg}$. 


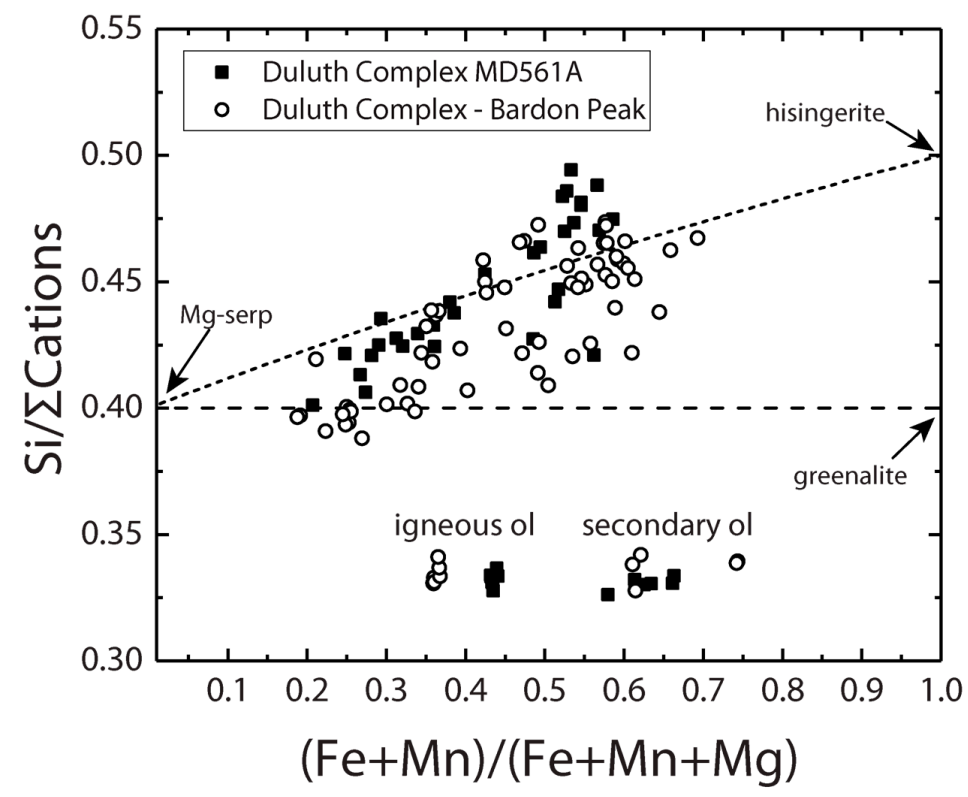

Figure 2. Formula proportions from electron microprobe spot analyses of phyllosilicate and olivine (igneous and secondary) in two Duluth Mafic Complex peridotites. Dashed lines from Figure 1.

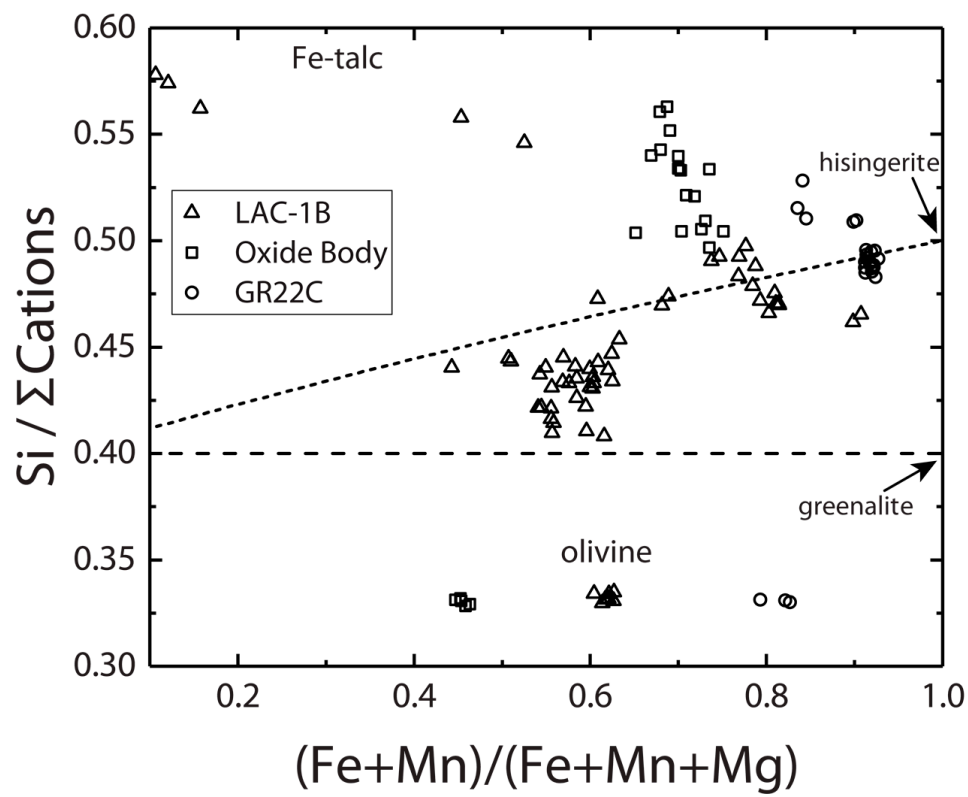

Figure 3. Formula proportions from electron microprobe spot analyses of phyllosilicate and igneous olivine in three Laramie Anorthosite Complex metaperidotites and gabbros. Dashed lines from Figure 1.

\subsubsection{Laramie Complex}

We also examined samples of peridotite ("Oxide Body"), troctolite (LAC-1B), and olivine gabbro (GR-22C) from the layered anorthositic Laramie Complex (Wyoming, USA) that possess igneous olivine more Fe-rich than the Duluth peridotites, namely $\mathrm{Fa}_{46}, \mathrm{Fa}_{61-63}$, and $\mathrm{Fa}_{79-82}$, respectively (Figure 3). Unlike the Duluth Complex samples, no secondary fayalite was found in the Laramie rocks. The degree of serpentinization in all samples is estimated at under $\sim 5 \%$, with serpentine-hisingerite mostly occurring in cross-cutting replacement veins. Similar to the Duluth Complex samples [26], the veins do not form the classic mesh-texture commonly associated with ophiolite serpentinites. None of the Laramie Complex samples exhibit the continuous spread in compositions from $\mathrm{Mg}$-serpentine to $\mathrm{Mg}$-hisingerite that characterizes the Duluth Complex samples. 
The "Oxide Body" sample is from a magnetite-ilmenite body in the Sybille monzosyenite of the Laramie Complex. Its igneous olivine $\left(\mathrm{Fa}_{46}\right)$ is the most magnesian of the three Laramie Complex samples, but similar in composition to the MD561 sample of the Duluth Complex. In this sample, the hisingerite is sufficiently Mg-and Si-rich to plot entirely above the compositional lid (Figure 3). The steep negative trend of Si-rich spot compositions in two of our samples in the $\mathrm{X}_{\mathrm{Fe}}$-range 0.7 to 0.8 (Figure 3) could be interpreted as indicative of contamination by $\mathrm{Mg}$-bearing saponite.

Troctolite sample LAC-1B is from the layered zone of the Poe Mountain anorthosite. Its igneous olivine $\left(\mathrm{Fa}_{61-63}\right)$ is similar in composition to the secondary olivine observed in the Duluth Complex samples. The compositional range of phyllosilicates filling cracks in igneous olivine in LAC-1B extends from $\mathrm{X}_{\mathrm{Fe}}=0.44$ to 0.90 , although there is a sizeable cluster of compositions (Figure 3) at $\mathrm{X}_{\mathrm{Fe}}=0.54-0.63$ and $\mathrm{Si} / \Sigma$ Cations $=0.41-0.45$ (Table 1 ). In general, this cluster is more greenalitic and less hisingerite-rich than the $\mathrm{Mg}$-hisingerite clusters in the Duluth samples. Its $\mathrm{X}_{\mathrm{Fe}}$ overlaps that of the igneous olivine; thus, in this respect, the alteration would appear to be nearly isochemical (but, see below). Our analyses yielded no evidence of initial production of an $\mathrm{Mg}$-serpentine such as lizardite ( \pm magnetite). The clusters of more Fe-rich (hisingeritic) compositions in sample LAC-1B (Figure 3) could have resulted from a modest $\mathrm{Mg}$ loss late in the alteration. Interestingly, talc present in this sample varies widely in iron content, in some cases having intergrown with the more greenalitic material.

Sample GR-22C is an olivine-gabbro xenolith from the Laramie Anorthosite Complex, with fayalitic primary olivine ( $\mathrm{Fa}_{79-82}$ ). It contains near end-member hisingerite, with $\mathrm{X}_{\mathrm{Fe}}=0.92$ and $\mathrm{Si} / \Sigma$ Cations $=0.49$, formed through alteration of the olivine (Figure 3). Some analyzed spots of slightly more magnesian hisingerite extend above the theoretical lid of the compositional envelope, showing a similar steeply dipping trend towards the hisingerite analyses as the Oxide Body analyses. As with the Oxide Body sample above, this elevated $\mathrm{Si} / \Sigma$ Cations ratio is potentially due to contamination by Mg-bearing saponite.

Together, the frequency in both the Duluth and Laramie Complex analyses of compositions in the intermediate- $X_{\mathrm{Fe}}$ serpentine-hisingerite range argues strongly against immiscibility between serpentine and hisingerite. As discussed below, the variable compositions we report, including hiatuses from sample to sample, reflect the influence of complex spatial and temporal controls on chemical potentials in our samples rather than actual miscibility gaps.

\subsection{Ores, Banded Iron Formation and Nakhla Meteorite}

A review of the literature shows that the compositional range of iron-rich serpentines including hisingerite derives overwhelmingly from occurrences in ore deposits and banded iron formation (BIF). To demonstrate the range of compositions in these samples, we collected analyses from a wide range of sources (Figure 4). It is clear that, in the ore and BIF samples, the intermediate $\mathrm{Mg}$-serpentine plus hisingerite solid solutions present in ferroan peridotites described above are not represented. The only exceptions to this generalization are provided by altered olivine in gabbro and diabase, including Martian nakhlite, and some hydrothermal vein deposits in volcanic rocks. There is a historical reason for these contrasting observations between ores and mafic complexes, namely use of EMP techniques in the last five or so decades. On the other hand, the compositional similarity we can now see between Mg-hisingerite in the type nakhlite and the Laramie Ore Body sample (analysis spots in Figures 3 and 4, averages in Table 1 ) is truly remarkable; this includes their steep negative trend on our compositional diagram.

Figure 4 shows that, for greenalite, throughout the range in $\mathrm{X}_{\mathrm{Fe}}$, the ratio $(\mathrm{Si}+\mathrm{Al} / 2) / \Sigma$ Cations is greater than the ideal 0.40 . This feature has been known for some time $[38,39]$. The ratio rises with increase in $\mathrm{X}_{\mathrm{Fe}}$, and is greatest for the most Fe-rich samples from BIFs. It is a deficiency in $\mathrm{Fe}+\mathrm{Mg}$ that rises to the point where, with the ratio $\mathrm{Si} / \Sigma$ Cations exceeding 0.45 (Figure 4), some examples [40-43] could be mistaken for hisingerite. Nonetheless, Mössbauer spectroscopy shows the presence in greenalite of 11.3 and $7.4 \mathrm{wt} . \% \mathrm{Fe}_{2} \mathrm{O}_{3}$ on octahedral sites [6]. While this is consistent with the substitution in greenalite of some hisingerite component, natural greenalite, like antigorite, 
is a modulated sheet silicate. Modulation involves periodic in-plane inversions of tetrahedral layers that serve to minimize the energetic consequence of octahedral-tetrahedral cation-size misfit $[44,45]$. This results in some loss of octahedral cations and consequently an elevated ratio $\mathrm{Si} /(\mathrm{Mg}+\mathrm{Fe})$ relative to the ideal 2:3 of serpentine. Unfortunately, we do not know the relative contributions of ${ }^{[6]} \square \mathrm{Fe}^{3+}$ (hisingerite) substitution and ${ }^{[6]} \square \mathrm{Fe}^{2+}$ due to modulation.

Relevant to this issue, newer analyses (this work, Figure 4) of the phyllosilicate alteration at the Overlook, Washington ore deposit [46] show $\mathrm{Si} / \Sigma$ Cations for some spots as high as 0.48 to 0.50 . Average anhydrous analysis totals (Table 1) of $95 \mathrm{wt} . \%\left(\right.$ all Fe$\left.{ }^{3+}\right)$ and $89.9 \mathrm{wt} . \%\left(\right.$ all Fe${ }^{2+}$ ) for these 2:2 spots strongly suggest that they contain primarily ferrous rather than ferric iron, indicating that they are not hisingerite, like the similarly plotting Laramie Complex sample GR22C (Figure 3), for example. As a result, we choose a more appropriate formula cation charge of 12 for this material in Table 1. These cation proportions and their structural implications (high abundance of tetrahedral sheet inversions, "small saucer-shaped islands") are similar to those of the Mn-silicate caryopilite [45]. This hitherto unknown "high-Si" greenalite at Overlook may be viewed as an (extreme) caryopilite analogue.

Also plotted in Figure 4 are literature analyses of hisingerite that are largely from ore deposits. Most of these analyses fall in the region above $(\mathrm{Si}+\mathrm{Al} / 2) / \Sigma$ Cations $=0.50$ and are, thus, Si-enriched in comparison to the ideal hisingerite formula: $\square \mathrm{Fe}^{3+}{ }_{2} \mathrm{Si}_{2} \mathrm{O}_{5}(\mathrm{OH})_{4} \cdot \mathrm{nH}_{2} \mathrm{O}$. We also plotted hisingerite spot analyses from the type Nakhla Martian meteorite (Table 1) and two Lafayette nakhlite analyses from Hicks et al. [47], as well as Mg-hisingerite from olivine gabbros/diabases, and veins in volcanic rocks.

Hisingerite has a halloysite-like crystal structure, although transmission electron microscope (TEM) images show mainly part-spheres [24]. Its X-ray diffraction (XRD) peaks tend to be broad, but nevertheless distinct enough to permit identification of hisingerite in mixtures of hisingerite and other phyllosilicates [48]. Eggleton and Tilley [24] found no evidence of tetrahedral inversions in their examined hisingerites and concluded that the structure was (like chrysotile) not modulated. This observation implies that the reason for the common Si-excess in hisingerite analyses is not structural, as partly the case in greenalite, but likely due to the presence of some contamination by a clay mineral such as nontronite or saponite, for which there is XRD evidence in some cases [24,48]. This conclusion seems valid despite the extraordinary geological diversity of the samples plotted in Figure 4.

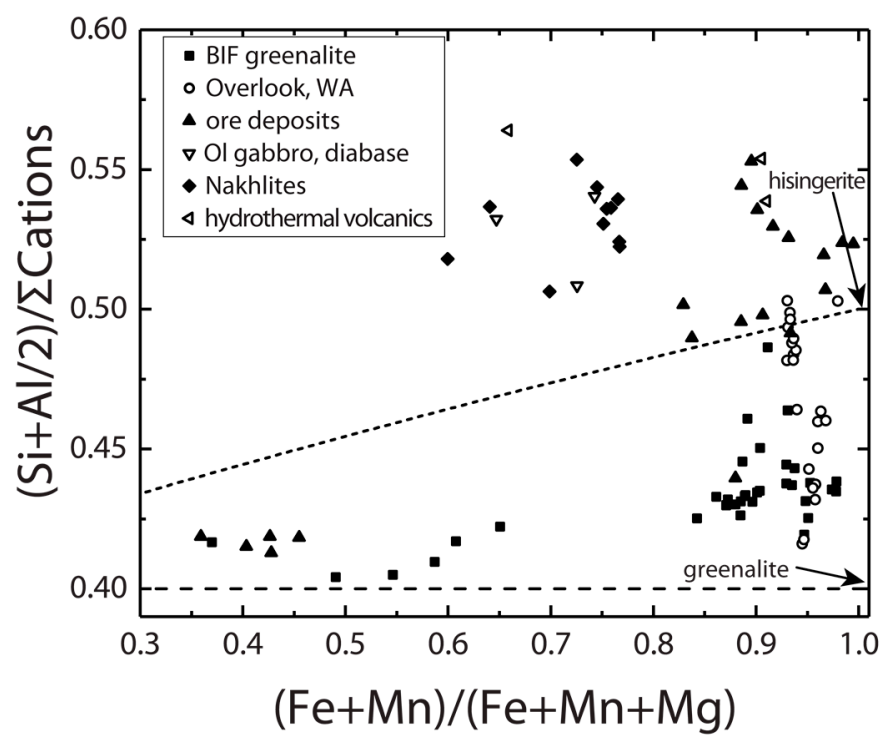

Figure 4. Electron microprobe (EMP) spot analyses of Martian nakhlite meteorite hisingerite, and Overlook greenalite (this work), as well as numerous literature analyses of greenalite and hisingerite in diverse geological environments [6,24,40-43,45,47,49-65]. Al/2 is included in the Si count because, unlike in peridotites, $\mathrm{Al}_{2} \mathrm{O}_{3}$ in many of the literature samples is greater than $1.0 \mathrm{wt} . \%$. 


\section{Discussion of Compositional and Environmental Controls}

\subsection{Reaction Conditions Leading to Mg Mobility}

Because fayalitic olivine $\left(\mathrm{Fa}_{58-79}\right)$ is a byproduct (Figure 2) of the Duluth Complex alteration, we infer that the attendant fluid was hydrothermal in origin and not meteoric; in other words, the observed phyllosilicates were not generated during weathering. In sample MD561, secondary fayalite $\mathrm{Fa}_{78-79}$ is associated in a microvein with serpentine having $\mathrm{X}_{\mathrm{Fe}}=0.25$ [26]. When preserved, the earliest generation of serpentine in the Duluth samples is Fe-depleted compared to the igneous olivine, with $\mathrm{X}_{\mathrm{Fe}} \approx 0.09$ (Figures 3, 6 and 12 in Evans et al. [26]). Increasing Fe content of olivine serves to increase its stability in the presence of water to lower temperatures (e.g., Figure 15 in Evans et al. [26]), such that end-member fayalite may be stable to temperatures as low as $\sim 200{ }^{\circ} \mathrm{C}$, whereas Fo 90 , under similar reaction conditions, is unstable at temperatures below $325^{\circ} \mathrm{C}$ [15]. The growth of fayalitic olivine and high-Fe chamosite as byproducts of the serpentinization reaction, which most likely occurred at relatively low temperatures (e.g., $\sim 20{ }^{\circ} \mathrm{C}$ [26]) attests to whole-rock removal of $\mathrm{Mg}$ by the infiltrating fluid and a resultant increase in the $\mathrm{FeMg}_{-1}$ exchange potential of the system.

Although Mg export from a serpentinizing rock may be surprising, given the exceptionally low solubility of Mg in typical seafloor hydrothermal fluids (e.g., Reference [66]), there is documented evidence of Mg mobility in the ultramafic-hosted Rainbow hydrothermal system on the mid-Atlantic Ridge [67]. At Rainbow, it is thought that the hydrothermal alteration of olivine-bearing troctolites or gabbros gives rise to the elevated $(\sim 1.65 \mathrm{mmol} / \mathrm{kg}) \mathrm{Mg}$ concentrations observed in the high-temperature $\left(360{ }^{\circ} \mathrm{C}\right)$, low-pH $\left(\mathrm{pH}_{\text {in situ }} \approx 5\right)$ vent fluids. Similar to the Duluth Complex system, igneous olivine ( $\mathrm{Fa}_{10}$ in the seafloor environment) can achieve thermodynamic equilibrium or recrystallize to more thermodynamically stable olivine compositions in aqueous solutions at the inferred "reaction zone" temperature $\left(\sim 400{ }^{\circ} \mathrm{C}\right.$ [67]) for the Rainbow hydrothermal system [15]. At Rainbow, the metasomatic loss of $\mathrm{Mg}$ is inferred to be associated with the presence of magnetite, talc, and chlorite solid solution [67]. In our Duluth Complex samples, the relative lack of primary aluminous phases (i.e., $\lesssim 15 \%$ plagioclase) dictates that the chlorite (chamosite)-forming reaction is less prevalent than the hisingerite-forming reaction. Indeed, in the samples we investigated, the metasomatic loss of $\mathrm{Mg}$ primarily drove a progressive increase in hisingerite component in the serpentine solid solution. Although our Duluth Complex samples are plagioclase-poor, chlorite solid solutions are a more prevalent alteration product in other zones of the Duluth Complex, which can contain up to $\sim 80 \%$ plagioclase [68]. In the Laramie Complex samples, there is little or no early-formed Mg-serpentine, suggesting Fe-enrichment (Mg-loss) possibly began early in the alteration process. Figure 3 suggests that serious $\mathrm{Mg}$ loss from the system may have been episodic.

\subsection{Silica Activity and Oxidation State of Hisingerite-Forming Solutions}

The presence of secondary fayalite $\left(\mathrm{Fa}_{53-80}\right)$ associated texturally (e.g., in olivine cracks and marginally attached to the igneous olivine) with serpentine and magnetite in three samples of altered Duluth Complex peridotite [26] shows that, in these cases, redox conditions $\left(\log f_{\mathrm{O}_{2}}\right)$ accompanying hydrothermal alteration were, at least for a time, little elevated over those of the fayalite-magnetite-quartz (FMQ) buffer. The hisingerite-rich serpentine observed in our EMP analyses of Duluth Complex phyllosilicates (Figure 2) likely grew both during and after hydrothermal fayalite formation. This reaction would have been accompanied by a progressively increasing $\mathrm{Fe} / \mathrm{Mg}$ ratio in the reactant solution, driven by the previously discussed Mg export from the system. To a certain degree, the increased concentration of $\mathrm{Fe}^{2+}$ alone would have sufficed to increase $\mathrm{Fe}^{3+}$, since the relative proportions of $\mathrm{Fe}^{2+}$ and $\mathrm{Fe}^{3+}$ in solution are maintained (at fixed $\mathrm{T}$ and $f_{\mathrm{O}_{2}}$ ) by a redox equilibrium in a reaction scheme analogous to the redox contours for the oxy-biotite system [69]. This explanation is insufficient, however, because, as our analyses show, isopleths of $\mathrm{Fe}^{3+} / \Sigma \mathrm{Fe}$ are crossed as Fe content in the greenalite-hisingerite alteration products increases (Figures 1 and 2). Thus, we must infer gradual changes in other solution parameters in order to yield increasingly hisingerite-rich serpentine. Simple 
thermodynamic calculations using methods and data described in Section 2.2 can help constrain these solution parameters.

Because the earlier-formed secondary fayalite is well preserved in Duluth Complex samples [26], any hisingerite-producing hydrothermal alteration must have been capable of maintaining fayalite stability. This could have been accomplished through increases in $a_{\mathrm{SiO}_{2}}$ associated with plagioclase destabilization, and decreases in $a_{\mathrm{H}_{2}}$ associated with infiltration of a comparatively (but not extremely) oxidizing fluid (Figure 5). In this regard, it is important to note that, although the $f_{\mathrm{O}_{2}}$ fixed by the FMQ buffer decreases from $\sim 10^{-35}$ at $300^{\circ} \mathrm{C}$ to $10^{-45}$ at $200^{\circ} \mathrm{C}$ and $10^{-52}$ at $150^{\circ} \mathrm{C}$ and $1 \mathrm{kbar}$ (which, overall, suggests a shift to more reducing conditions with decreasing temperature), the $a_{\mathrm{H}_{2}}$ in equilibrium with this assemblage over the same interval decreases from $10^{-2.7}$ at $300^{\circ} \mathrm{C}$ to $10^{-3.5}$ at $200{ }^{\circ} \mathrm{C}$ (Figure 5) and $10^{-4}$ at $150^{\circ} \mathrm{C}$. If we assume that the secondary olivine formed at higher temperature than the hisingerite, these calculations indicate that the stability of early-formed fayalitic olivine (represented here through the FMQ buffer) could have been feasibly maintained even as hisingerite was growing from the reacting solution. Indeed, the FMQ buffer plots are well within the calculated hisingerite stability field at $200{ }^{\circ} \mathrm{C}$ and $1 \mathrm{kbar}$ (Figure 5).

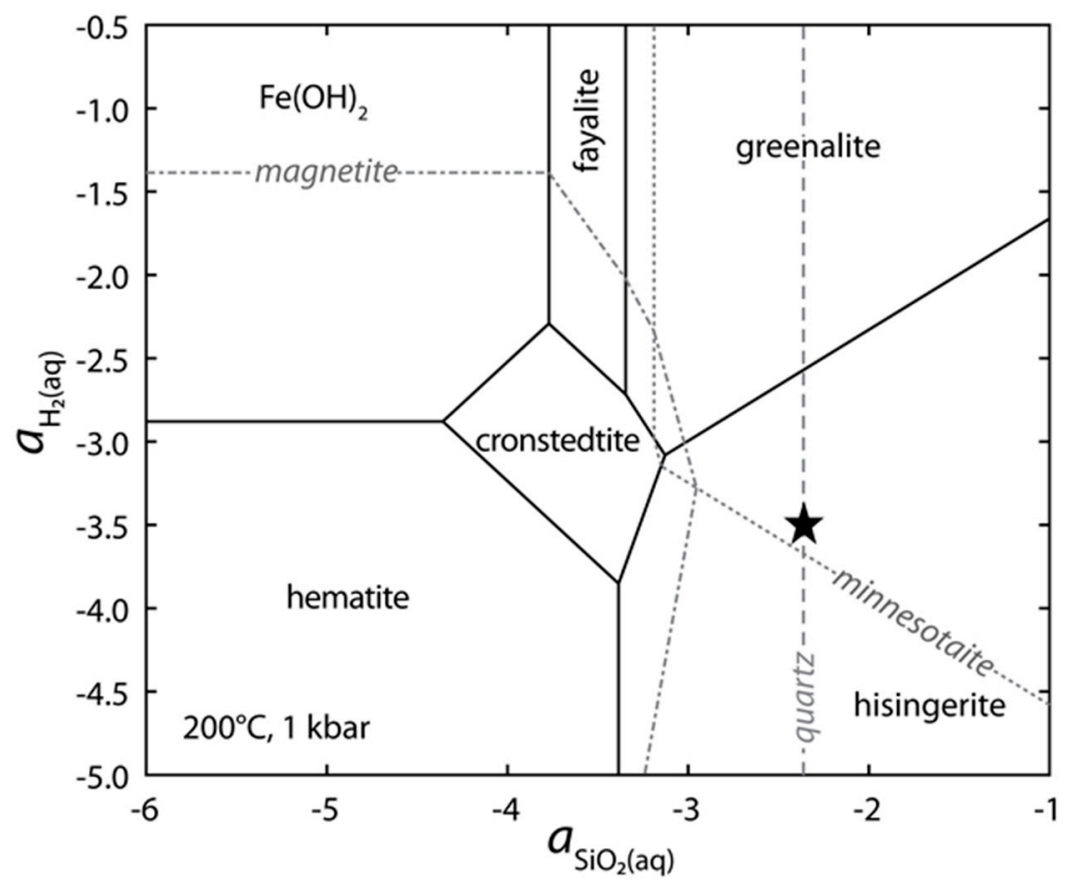

Figure 5. Stability fields of Fe-Si-O-H (FSOH)-system phyllosilicates in terms of the activities of aqueous $\mathrm{H}_{2}\left(a_{\mathrm{H}_{2}}\right)$ and $\mathrm{SiO}_{2}\left(a_{\mathrm{SiO}_{2}}\right)$ at $200{ }^{\circ} \mathrm{C}$ and $1 \mathrm{kbar}$. The stability bounds for magnetite and minnesotaite, as well as the solubility of quartz, are plotted as dashed lines. The black star represents the fayalite-magnetite-quartz (FMQ) buffer.

The preference to form hisingerite solid solutions (octahedral $\mathrm{Fe}^{3+}$ ) rather than cronstedtite (i.e., ferri-tschermaks) solid solutions (see Section 1.1) in the analyzed mafic complex serpentines likely reflects elevated $a_{\mathrm{SiO}_{2}}$ in the reactant fluid during the alteration process (Figure 5). This increased $a_{\mathrm{SiO}_{2}}$ could have been fueled by plagioclase dissolution during hydrothermal alteration of these mineralogically complex, magmatically evolved peridotites. However, the overall preference for hisingeritic rather than greenalitic compositions in the Duluth Complex samples (and some of the Laramie Complex samples) cannot be interpreted in terms of elevated $a_{\mathrm{SiO}_{2}}$ alone, since hisingerite and greenalite are similarly stable as a function of $a_{\mathrm{SiO}_{2}}$. Rather, the relative stability of these two phases must be interpreted in terms of their stability as a function of the oxidation state of the reactant fluid, i.e., the preference for hisingerite formation may be attributed to solutions with decreased $a_{\mathrm{H}_{2}}$ (elevated $f_{\mathrm{O}_{2}}$ ) relative to those which form greenalite. Nonetheless, as we have now demonstrated, 
hisingerite and greenalite are mutually soluble. Thus, they should in fact occupy a continuous field, with $\mathrm{Fe}^{3+} / \Sigma \mathrm{Fe}$ isopleths similar to those plotted in Figure 1, at elevated $a_{\mathrm{SiO}_{2}}$ in Figure 5. The oxidation of Fe during hisingerite formation at this elevated $a_{\mathrm{SiO}_{2}}$ likely released hydrogen, which would have driven the system toward progressively more reducing conditions (upward on Figure 5) and likely stabilized phyllosilicates increasingly rich in greenalite.

Importantly, the field representing greenalite-hisingerite solid solutions in Figure 5 largely overlaps with the conditions occupied by minnesotaite (i.e., the Fe-bearing analog of talc). This suggests that the tendency to form serpentine-hisingerite solid solutions rather than talc-minnesotaite solid solutions must be controlled by fluid chemistry variables other than oxidation state and $a_{\mathrm{SiO}_{2}}$, such as $a_{\mathrm{Mg}^{++}}$or $\mathrm{pH}$. A future reaction-path modeling study, employing the thermodynamic data used in the creation of Figure 5, will help to place improved constraints on these other variables.

\section{Conclusions}

Low-temperature hydrothermal alteration of intermediate FeMg-olivine in ferroan peridotite and gabbro produces variable serpentine-hisingerite solid solutions substantially enriched in both ferrous and ferric iron. The compositions of these phyllosilicate alteration products are very different from the well-studied serpentines that occur in altered oceanic and ophiolitic peridotite. Nevertheless, these alteration products also contain abundant $\mathrm{Fe}^{3+}$ in the form of a hisingerite component, suggesting that hydrogen gas is still produced during hydrothermal alteration of these more evolved protoliths. In some cases, if not all, the alteration products yield considerable evidence for significant Mg export from the reacting rock, which is in direct contrast to the common observation of Mg enrichment in phyllosilicate alteration phases in oceanic and ophiolitic serpentinites. Importantly, some Martian rocks are similarly evolved magmatically [70], indicating that the processes and phyllosilicate assemblages observed in the rocks studied here are more directly relevant to those occurring on Mars than "traditional" serpentinites.

Author Contributions: B.M.T. and B.W.E. acquired the samples for EMP analysis by B.W.E. and S.M.K. B.W.E. compiled the literature data plotted in Figure 4. B.M.T. produced the thermodynamic models and interpreted them. B.M.T. and B.W.E. wrote and edited the manuscript. All authors contributed to the scientific interpretation of the presented data.

Funding: B.M.T.'s involvement in this research was supported by the Natural Sciences and Engineering Research Council of Canada through Discovery Grant RGPIN-2018-03800, by a Geological Society of America student research grant, and by the Early Career Research Bursary from the Environmental Mineralogy Group of the Mineralogical Society of GB and Ireland. B.W.E. was supported by the University of Washington, Seattle.

Acknowledgments: We thank Stephen Guggenheim and two reviewers for helpful comments, and B. Ronald Frost and Anthony J. Irving for providing samples.

Conflicts of Interest: The authors declare no conflict of interest.

\section{References}

1. Evans, B.W.; Hattori, K.; Baronnet, A. Serpentinite: What, why, where? Elements 2013, 9, 99-106. [CrossRef]

2. O'Hanley, D.S. Serpentinites; Oxford University Press: Oxford, UK, 1996.

3. Sleep, N.H.; Bird, D.K.; Pope, E.C. Serpentinite and the dawn of life. Philos. Trans. R. Soc. B Biol. Sci. 2011, 366, 2857-2869. [CrossRef] [PubMed]

4. Klein, F.; Bach, W.; Jöns, N.; McCollom, T.; Moskowitz, B.; Berquó, T. Iron partitioning and hydrogen generation during serpentinization of abyssal peridotites from $15^{\circ} \mathrm{N}$ on the Mid-Atlantic Ridge. Geochim. Cosmochim. Acta 2009, 73, 6868-6893. [CrossRef]

5. Wicks, F.J.; O’Hanley, D.S. Serpentine minerals: Structures and petrology. In Reviews in Mineralogy: Volume 19, Hydrous Phyllosilicates; BookCrafters, Inc.: Chelsea, MI, USA, 1988; pp. 91-167.

6. Evans, B.W.; Dyar, M.D.; Kuehner, S.M. Implications of ferrous and ferric iron in antigorite. Am. Mineral. 2012, 97, 184-196. [CrossRef]

7. Brindley, G.W.; Zussman, J. A Structural Study of the thermal transformation of serpentine mineral to forsterite. Am. Mineral. 1957, 42, 461-474. 
8. Faust, G.; Fahey, J. The Serpentine-Group Minerals; The U.S. Government Publishing Office: Washington, DC, USA, 1962.

9. Whittaker, E.J.W.; Wicks, F.J. Chemical differences among the serpentinte "polymorphs": A discussion. Am. Minerol. 1970, 55, 1025-1047.

10. Wicks, F.J.; Plant, A.G. Electron-microprobe and xray-microbeam studies of serpentine textures. Can. Mineral. 1979, 17, 785-830.

11. McCollom, T.M.; Shock, E.L. Geochemical constraints on chemolithoautotropic metabolism by microorganisms in seafloor hydrothermal systems. Geochim. Cosmochim. Acta 1997, 61, 4375-4391. [CrossRef]

12. Klein, F.; Bach, W.; Humphris, S.E.; Kahl, W.A.; Jiöns, N.; Moskowitz, B.; Berquó, T.S. Magnetite in seafloor serpentinite-Some like it hot. Geology 2014, 42, 135-138. [CrossRef]

13. Evans, B.W.; Kuehner, S.M.; Chopelas, A. Magnetite-free, yellow lizardite serpentinization of olivine websterite, Canyon Mountain complex, N.E. Oregon. Am. Mineral. 2009, 94, 1731-1734. [CrossRef]

14. Beard, J.S.; Frost, B.R. The stoichiometric effects of ferric iron substitutions in serpentine from microprobe data. Int. Geol. Rev. 2017, 59, 541-547. [CrossRef]

15. Klein, F.; Bach, W.; McCollom, T.M. Compositional controls on hydrogen generation during serpentinization of ultramafic rocks. Lithos 2013, 178, 55-69. [CrossRef]

16. Evans, K.A.; Powell, R.; Frost, B.R. Using equilibrium thermodynamics in the study of metasomatic alteration, illustrated by an application to serpentinites. Lithos 2013, 168-169, 67-84. [CrossRef]

17. Malvoisin, B. Mass transfer in the oceanic lithosphere: Serpentinization is not isochemical. Earth Planet. Sci. Lett. 2015, 430, 75-85. [CrossRef]

18. Caruso, L.J.; Chernosky, J.V.J. The stability of lizardite. Can. Mineral. 1979, 17, 757-769.

19. O'Hanley, D.S.; Dyar, M.D. The composition of lizardite $1 \mathrm{~T}$ and the formation of magnetite in serpentinites. Am. Mineral. 1993, 78, 391-404.

20. O'Hanley, D.S.; Dyar, M.D. The composition of chrysotile and its relationship with lizardite. Can. Mineral. 1998, 36, 727-739.

21. Votyakov, S.L.; Chashchukhin, I.S.; Galakhova, O.L.; Gulyaeva, T.Y. Crystal Chemistry of Lizardite as an Indicator of Early Serpentinization in Ultramafic Rocks. I. Compositional and Structural Features of the Mineral According to Spectroscopic Data. Geochem. Int. 2005, 43, 947-965.

22. Evans, B.W. Control of the products of serpentinization by the $\mathrm{Fe}^{2+} \mathrm{Mg}_{-1}$ exchange potential of olivine and orthopyroxene. J. Petrol. 2008, 49, 1873-1887. [CrossRef]

23. Fuchs, Y.; Linares, J.; Mellini, M. Mossbauer and infrared spectrometry of lizardite-1T from Monte Fico, Elba. Phys. Chem. Miner. 1998, 26, 111-115. [CrossRef]

24. Eggleton, R.A.; Tilley, D.B. Hisingerite: A ferric kaolin mineral with curved morphology. Clays Clay Miner. 1998, 46, 400-413. [CrossRef]

25. Smith, K.L.; Milnes, A.R.; Eggleton, R.A. Weathering of basalt: Formation of iddingsite. Clays Clay Miner. 1987, 35, 418-428. [CrossRef]

26. Evans, B.W.; Kuehner, S.M.; Joswiak, D.J.; Cressey, G. Serpentine, iron-rich phyllosilicates and fayalite produced by hydration and Mg depletion of peridotite, Duluth Complex, Minnesota, USA. J. Petrol. 2017, 58, 495-512. [CrossRef]

27. Van Aken, P.A.; Liebscher, B.; Styrsa, V.J. Quantitative determination of iron oxidation states in minerals using Fe L 2,3-edge electron energy-loss near-edge structure spectroscopy. Phys. Chem. Miner. 1998, 25, 323-327. [CrossRef]

28. Andreani, M.; Muñoz, M.; Marcaillou, C.; Delacour, A. $\mu$ XANES study of iron redox state in serpentine during oceanic serpentinization. Lithos 2013, 178, 70-83. [CrossRef]

29. Debret, B.; Andreani, M.; Muñoz, M.; Bolfan-Casanova, N.; Carlut, J.; Nicollet, C.; Schwartz, S.; Trcera, N. Evolution of Fe redox state in serpentine during subduction. Earth Planet. Sci. Lett. 2014, 400, 206-218. [CrossRef]

30. Bethke, C.M.; Farrell, B.; Yeakel, S. The Geochemist's Workbench ${ }^{\circledR}$ Release 12.0-Reaction Modeling Guide; Aqueous Solutions, LLC: Champaign, IL, USA, 2018; ISBN 9781597180948.

31. Kong, X.Z.; Tutolo, B.M.; Saar, M.O. DBCreate: A SUPCRT92-based program for producing EQ3/6, TOUGHREACT, and GWB thermodynamic databases at user-defined T and P. Comput. Geosci. 2013, 51, 415-417. [CrossRef] 
32. Helgeson, H.C.; Delany, J.M.; Nesbitt, H.W.; Bird, D.K. Summary and critique of the thermodynamic properties of the rock-forming minerals. Am. J. Sci. 1978, 278A, 229.

33. Sverjensky, D.A.; Harrison, B.; Azzolini, D. Water in the deep Earth: The dielectric constant and the solubilities of quartz and corundum to $60 \mathrm{~kb}$ and $1200^{\circ} \mathrm{C}$. Geochim. Cosmochim. Acta 2014, 129, 125-145. [CrossRef]

34. McCollom, T.M.; Bach, W. Thermodynamic constraints on hydrogen generation during serpentinization of ultramafic rocks. Geochim. Cosmochim. Acta 2009, 73, 856-875. [CrossRef]

35. Johnson, J.W.; Oelkers, E.H.; Helgeson, H.C. SUPCRT92: A software package for calculating the standard molal thermodynamic properties of minerals, gases, aqueous species, and reactions from 1 to 5000 bar and 0 to $1000{ }^{\circ}$ C. Comput. Geosci. 1992, 18, 899-947. [CrossRef]

36. Blanc, P.; Vieillard, P.; Gailhanou, H.; Gaboreau, S.; Gaucher, É.; Fialips, C.I.; Madé, B.; Giffaut, E. A generalized model for predicting the thermodynamic properties of clay minerals. Am. J. Sci. 2015, 315, 734-780. [CrossRef]

37. Tutolo, B.M.; Mildner, D.F.R.; Gagnon, C.V.L.; Saar, M.O.; Seyfried, W.E. Nanoscale constraints on porosity generation and fluid flow during serpentinization. Geology 2016, 44, 103-106. [CrossRef]

38. Jolliffe, F. A study of greenalite. Am. Mineral. 1935, 20, 405-425.

39. Gruner, J.W. The structure and chemical composition of greenalite. Am. Mineral. 1936, 21, 449-455.

40. Floran, R.J.; Papike, J.J. Petrology of the low-grade rocks of the Gunflint Iron-Formation, Ontario-Minnesota. Bull. Geol. Soc. Am. 1975, 86, 1169-1190. [CrossRef]

41. Gole, M. Low temperature retrograde minerals in metamorphosed Archean banded iron formations, western Australia. Can. Mineral. 1980, 18, 205-214.

42. Gole, M. Mineralogy and petrology of very-low-metamorphic grade Archaean banded iron-formations, Weld Range, Western Australia. Am. Mineral. 1980, 65, 8-25.

43. Klein, C.; Gole, M.J. Mineralogy and petrology of parts of the Marra Mamba iron formation, Hamersley Basin, Western Australia. Am. Mineral. 1981, 66, 507-525. [CrossRef]

44. Guggenheim, S.; Bailey, S.W. Structural aspects of greenalite and related minerals. Can. Mineral. 1982, 20, 1-18.

45. Guggenheim, S.; Eggleton, R.A. Modulated structures of greenalite and caryopilite: A system with long-range, in-plane structural disorder in the tetrahedra sheet. Can. Mineraoligist 1998, 36, 163-179.

46. Rasmussen, M.G.; Evans, B.W.; Kuehner, S.M. Low-temperature fayalite, greenalite, and minnesotaite from the overlook gold deposit, Washington: Phase relations in the system $\mathrm{FeO}-\mathrm{SiO}_{2}-\mathrm{H}_{2} \mathrm{O}$. Can. Mineral. 1998, 36, 147-162.

47. Hicks, L.J.; Bridges, J.C.; Gurman, S.J. Ferric saponite and serpentine in the nakhlite Martian meteorites. Geochim. Cosmochim. Acta 2014, 136, 194-210. [CrossRef]

48. Milliken, R.; Bish, D.L. Distinguishing hisingerite from other clays and its importance for Mars. In Proceedings of the 45th Lunar and Planetary Science Conference, Woodlands, TX, USA, 17-21 March 2014; Volume 343, p. 2251.

49. Baker, J.H. Greenalite, Mg-rich minnesotaite and stilpnomelane from the Oesjoeberg and Sirsjoeberg iron-ore mines, Hjulsjoe, W. Bergslagen, Sweden. Mineral. Mag. 1985, 49 Pt 4, 611-613. [CrossRef]

50. Dietrich, V. Ilvait, Ferroantigorit und Greenalith als Begleiter Oxidisch-Sulfidischer Vererzungen in den Oberhalbsteiner Serpentiniten; Geologisches Institut der Eidg. Technischen Hochschule und der Universität Zürich: Zürich, Switzerland, 1972.

51. Eggleton, R.A.; Pennington, J.H.; Freeman, R.S.; Threadgold, I.M. Structural aspects of the hisingerite-neotocite series. Clay Miner. 1983, 18, 21-31. [CrossRef]

52. Floran, R.J.; Papike, J.J. Mineralogy and petrology of the Gunflint Iron Formation, Minnesota-Ontario: Correlation of compositional and assemblage variations at low to moderate grade. J. Petrol. 1978, 19, $215-288$. [CrossRef]

53. Hawkins, A.C.; Shannon, E.V. Canbyite, a new mineral. Am. Mineral. 1924, 9, 1-5.

54. Klein, C. Greenalite, stilpnomelane, minnesotaite, crocidolite and carbonates in a very low-grade metamorphic Precambrian Iron-Formation. Can. Mineral. 1974, 12, 475-498.

55. Kohyama, N.; Sudo, T. Hisingerite occurring as a weathering product of iron-rich saponite. Clays Clay Miner. 1975, 23, 215-218. [CrossRef]

56. Lindqvist, B.; Jansson, S. On the crystal chemistry of hisingerite. Am. Mineral. 1962, 47, 1356-1362.

57. Manceau, A.; Ildefonse, P.; Hazemann, J.L.; Flank, A.M.; Gallup, D. Crystal chemistry of hydrous iron silicate scale deposits at the Salton Sea geothermal field. Clays Clay Miner. 1995, 43, 304-317. [CrossRef] 
58. Mustoe, G.E. Hisingerite-A rare iron mineral from Walker Valley, Skagit County, Washington. Washingt. Geol. 1996, 24, 14-19.

59. Schwarz, G.M. On the nature and origin of hisingerite from Parry Sound, Ontario. Am. Mineral. 1924, 9, 141-144.

60. Shayan, A. Hisingerite material from a basalt quarry near Geelong, Victoria, Australia. Clays Clay Miner. 1984, 32, 272-278. [CrossRef]

61. Sudo, T.; Nakamura, T. Hisingerite from Japan. Am. Mineral. 1952, 37, 618-621.

62. Whelan, J.A.; Goldich, S.S. New data for hisingerite and neotocite. Am. Mineral. 1961, 46, 1412-1423.

63. Wilshire, H.G. Alteration of olivine an orthopyroxene in basic lavas and shallow intrusions. Am. Mineral. 1958, 43, 120-147.

64. Zajak, I.S. The Stratigraphy and Mineralogy of the Sokoman Iron Formation in the Knob Lake Area, Quebec and Newfoundland; University of Michigan: Ann Arbor, MI, USA, 1972.

65. Bailey, S.W. Structures and compositions of other trioctahedral 1:1 phyllosilicates. Rev. Mineral. Geochem. 1988, 19, 169-188.

66. Janecky, D.R.; Seyfried, W.E. Hydrothermal serpentinization of peridotite within the oceanic crust: Experimental investigations of mineralogy and major element chemistry. Geochim. Cosmochim. Acta 1986, 50, 1357-1378. [CrossRef]

67. Seyfried, W.E.; Pester, N.J.; Ding, K.; Rough, M. Vent fluid chemistry of the Rainbow hydrothermal system ( $\left.36^{\circ} \mathrm{N}, \mathrm{MAR}\right)$ : Phase equilibria and in situ $\mathrm{pH}$ controls on subseafloor alteration processes. Geochim. Cosmochim. Acta 2011, 75, 1574-1593. [CrossRef]

68. Foster, M.E.; Hudleston, P.J. "Fracture cleavage" in the Duluth Complex, northeastern Minnesota (USA). Geol. Soc. Am. Bull. 1986, 97, 85-96. [CrossRef]

69. Wones, D.R.; Eugster, H.P. Stability of biotite: Experiment, theory, and application. Am. Mineral. 1965, 50, 1228-1272. [CrossRef]

70. Bish, D.L. X-ray Diffraction Results from Mars Science Laboratory: Mineralogy of Rocknest at Gale Crater. Science 2014, 341, 1-6. [CrossRef] [PubMed]

(C) 2019 by the authors. Licensee MDPI, Basel, Switzerland. This article is an open access article distributed under the terms and conditions of the Creative Commons Attribution (CC BY) license (http:/ / creativecommons.org/licenses/by/4.0/). 